\title{
THE ROLE OF GOVERNMENT AND CIVIL SOCIETY ORGANIZATIONS IN COMMUNITY DEVELOPMENT
}

Oleh:

\section{YENNI ROSANA}

\author{
Universitas Dehasen Bengkulu
}

\begin{abstract}
The government plays an important role in ensuring the country's development. Similarly, for a province; the government of a province should take actions to improve the quality of the province. However, besides the government there are the role of civil society organizations that could not be ignored. If the government and civil society organizations' perspectives are contradicting to each other, community will be living in ambiguous situation; there could be some of the community will choose to be in the civil society organizations' sides, or in support to the government. This essay will describe how the people in Aceh Province in Indonesia has experienced various challenge because of there were some contradictions between the government and certain civil society organizations. Therefore, it is necessary to have good cooperation between government and civil society organizations. Although the civil society organizations will act as oppositions or partners of government, but it should synergy with the main aims should be for the better life of the people; community development.
\end{abstract}

Keywords: government, civil society organizations, community, development

\section{INTRODUCTION}

Indonesia is the world's largest archipelago, a country that comprises more than 17.000 islands (Philips, 2005). At 1.919.440 square kilometres, Indonesia is the world's sixteenth largest country in terms of land area. More than 650 different languages and dialogues are spoken in the country that is divided into 33 provinces. As reported by Indonesian Statistics Bureau (2010), the population in Indonesia in 2008 is 240 million people.

For many people in the world when Indonesia is mentioned, what comes to mind is only Bali and Jakarta. This statement was fully well-known by Acehnese society who went overseas before a giant tsunami in Aceh in 2004. Only a small number of people in other countries know Aceh and the problems situated in the area. Then the situation is reflected in the title of a book written by John Martinkus, (2004): "Indonesia's secret war in Aceh" that is how Aceh, like an underground treasure that was kept in the protection by Indonesian government. In fact, the Acehnese communities were silenced and the media was controlled by government. That is why, the suffering of Acehnese's communities during the conflict was not widely known.

Conflict in Aceh started in 1976; Free Aceh Movement or Gerakan Aceh Merdeka (GAM) who demands Aceh's Independence was claimed as a separatist organisation. The military response from the Indonesian government not only killed GAM members and Indonesian military, many civilians 
also were killed during the conflict. This condition led to the establishment of numbers of civil society organisations in Aceh. However, conditions were not getting better. Many Acehnese's activists also got killed. According to the data, 12.000 people were killed during the conflict including civilians and activists. Then the conditions worsen and worsened (Martinkus, 2004).

In May 2003, the Indonesian President Megawati Sukarno Putri, declared the martial law in Aceh. Many GAM members, Aceh's activists and civilians left Aceh after that. They fled as refugees or asylum seekers into many countries all around the world. Most of them went to Malaysia, as it is the nearest neighbouring country (Kaur, 2007).

However, after the tsunami 2004, peace came to Aceh, the Indonesian government and GAM agreed to sign a peace agreement in Helsinki, Finland in August 2005. The Acehnese were tired, afflicted by the conflict and shocked by the tsunami. The Acehnese were exhausted with the unstable life, too much loss; the loss of property and the lives of their loved ones. The Acehnese have suffered mentally, physically, economically, the only thing that can stop all of this is justice for the Acehnese. In this essay, I will analyse what had been done by civil societies in Aceh during the conflict that lead to the confrontation and I will explore the relationship between civil society organisations in Aceh during and after the conflict. The reason for this is as a lesson of how to build a conducive and positive relationship between both parties to ensure the sustainable development. The position of civil society organizations that sometimes could be the opposition parties of the government; however, it could encourage the government to achieve higher level of development.

\section{LITERATURE REVIEW}

\section{Civil Society Organisations During Civil} War in Aceh

To begin, the definition of civil society organisation; in many articles, is defined as an organisation that is different from government, family and market. Moreover, some articles question whether family and market are included or not in a civil society organisation and it is still debatable. I would like to define a civil society organisation as a group of community that forms them self or are organised in an assembly to fight for their goals. Every organisation that are formed has goals and aims that can be different from one to another, but also can be similar even the same.

During the civil war in Aceh (19762005), Norway (2006, p.1) states "there was little room for civil society to operate". Particularly for men and youth associations, the togetherness of men and youth in a forum can result in a bias from the government. Although, within 30 years throughout the conflict, the organisations could not fully function, but this condition could not change this solid tradition.

In a response to the continuous conflict, Aceh was declared as a military zone known as Daerah Operasi Militer (DOM) from 1990 to 1998. Experiencing working for an organization that aims to reintegrate the ex-combatant and expolitical prisoners to be part of communities again from 2005 to 2007 in Aceh, the story from them are various and tense. In conclusion, at that time, the human rights abuses due to severe violence increasingly worried and haunted Acehnese at that time. Acehnese civil society organisations have been active locally, nationally and internationally to build the network at every level. The demands and initiative of the civil society organizations are show discrepancy but have the same aim for the better life of Acehnese. At the international level the social actors of civil society organisation were solidarity groups, Acehnese community abroad and international non-government organizations, their demands and initiatives were building capacity of civil society, justice and peace in Aceh. There were always controversies on what they want to 
be achieved. Meanwhile, to the ex-prisoners and ex-combatant's stories, each of them also has different stories that could never be recorded.

Furthermore, by exploring what had been done by civil society organizations in Aceh during the conflict that lead to the confrontation between government and civil society organisations. That caused not only the Gerakan Aceh Merdeka (GAM) or The Free Aceh Movement's members to become target of the military actions but student activists, social workers, journalists and civilians were also targeted when they were in the position to support the GAM that at that time was recognized as rebels.

There were many human rights groups which were formed in Aceh, such as Cordova (an NGO educating the public on civil society and Human rights), Koalisi NGO-HAM (a coalisation of Human Rights and NGO in Aceh), RATA (rehabilitation of torture victims in Aceh), PCC (People Crisis Center), SIRA (Aceh referendum Information Centre), LBH Aceh (Human right goups), and Kontras Aceh (the commission for involuntary disappearances and victims of violence in Aceh). Working with LBH Aceh, Kontras was compiling chronologies, building databases and preparing reports on human rights situation in Aceh. These activities followed by persistent advocacy at local, national and international level, forced the Indonesian government to declare and end Aceh as a military zone (Aguswandy 2005).

Aguswandy (2005), in the same article also states that the student movement began in early 1998, these groups were antimilitary. Some of these groups are mentioned below: SMUR (Student solidarity for the people), FARMIDIA (Muslim student's fronts for reform Aceh), KARMA (Aceh student coalition for reform). Also, women association played a big role in supporting victims of rape and gender based on violence under DOM, the name of this group is Flower Aceh.

At the international level, there are also some organisations that concentrate on
Aceh; they are Amnesty International, Human rights watch, and International Forum for Aceh (IFA). Despite increased world attention the situation in Aceh has not improved. In the late 1900s, SIRA, Kontras and SMUR were claimed by government as GAM sympathisers' organisations. That is a reason that leads to the relationship between government and these organisations mentioned breaking down. Many activists of these organisations were imprisoned, kidnapped, tortured and murdered. Their human rights were abused.

\section{Civil Society Organizations After Civil War}

As previously noted, the tsunami brought peace to Aceh, In August 2005, the Indonesian government and GAM agreed to sign a peace agreement in Helsinski, Finland (Kingsburry 2006). The circumstances of civil society organisation in Aceh have been changed. Organisations which were in conflict were considered anti government by the government, started to be a part of executors of development. Interestingly, Irwandi Yusuf, a former of GAM member was elected as Aceh's governor (local government leader), and Muhammad Nazar as the vice governor was a leader of the Aceh referendum Information Centre (SIRA) organisation, a civil society organisation that during the conflict was fully oppressed by the government. Relationship between government and civil society organisations has been changed from confrontation to be partnership and advocacy.

The Partnerships between government and civil society organisations obviously are seen in many events. Both parties are working together to maintain sustainable development through assistance and support from the organisation to government. Advocacy in the context is supposed to support and assist the government by critics and suggestions to maintain good governance and gender equality to ensuring the development is 
running as it should, relevant to mission and vision of countries' development.

Aceh nowadays is a province that has attained freedom without independence. Aceh is an autonomous province, that the voice of Acehnese is conveyed by the involvement of Acehnese local parties in the election in 2009. Indeed, the Legislative election in Aceh that was held in April 2009 was different with this in other provinces. While in other provinces the parties was involved in election is only 34 national parties. In Aceh, besides 34 national parties, six parties are from Aceh's local parties. Partai Aceh (PA) which is commanded by Muzakir Manaf, the former leader of GAM is one of the Aceh's local parties, this party won 47 seats in local parliament.

When peace has been achieved, then the synergy of work will be easier to be discussed. The government and civil society organizations could sit together for the better of the development and the improvement of social welfare. There could be not always the concession could be reach, however, the opposition could take role as the encouragement of the better community welfare that is by monitoring and/or supporting. On the other hand, when the concession is achieved that when there are no opposition parties that should be do not mean between government and civil society organizations are working on their need that could give detrimental effect to community such as corruption.

\section{CONCLUSION}

Fundamentally, in a country, the relationships of a civil society organisation cannot be separated from the government. These relationships can be as opposition, an advocacy or a partnership. In addition, also the relationship can be monitoring, delivering government services and as a link to the community. In addition, civil society organisations also can play a role in delivering government services and as a link between governments to community or the reverse of that as a liaison between the community and government. In Aceh, the relationship between government and some civil society groups, in the past experienced many challenges.

Good governance of countries always involves government and community in making decision. In this context, civil society organisations could take a part as a community representative to convey community voice to ensure the track chosen by government is relevant to the community need.

As mentioned, the depraved relationship was created during the conflict era. By this, I conclude it is important to disclose one to each other opinion in peace, to share the needs and knowledge between government and civil society organisations. Together, government and civil society organisations work to assist the community needs, to reduce poverty, provide good education and health services, to develop the country to enhance community development in Indonesia including the Aceh Province whether as oppositions or supporters to each other.

\section{REFERENCES}

Aguswandy. 2005. Breaking The Deadlock: Civil Society Engagement For Conflict Resolution. Aceh under martial law: conflict, violence and displacement, University of Oxford, refugee studies center, working paper no.24, p. 45-52, viewed 15 September 2010. http://www.rsc.ox.ac.uk/PDFs/working paper24.pdf

Badan Pusat Statistik. 2010. Indonesia. BPS, Jakarta, viewed : 14 September 2010, http://www.bps.go.id/aboutus.php?tabe $\underline{\text { l=1\&id_subyek }=12}$ 
Hedman, E. 2005. A state of emergency, a strategy of war; Internal displacement forced relocation and involuntary return in Aceh. Aceh under martial law: conflict, violence and displacement, University of Oxford, refugee studies center, working paper no.24, p. 7-12, viewed 15 september 2010.

http://www.rsc.ox.ac.uk/PDFs/working paper24.pdf

Kaur, K. 2007. Media Reporting On Refugees In Malaysia. UNEAC Asia Paper No.13, viewed 15 September 2010,

http://www.une.edu.au/asiacentre/PDF/ No13.pdf.
Martinkus, J. 2004. Indonesia's Secret War In Aceh. Random House Australia, Milsons Point, NSW.

Philips D.A. 2005. Modern World Nations: Indonesia. South Dakota State University, Chelsea House Publisher, Philadelphia, viewed 14 September 2010, retrieved from Academic Research Premier.

Norway. 2006. Aceh Civil Society, Royal Norwegian Embassy, Jakarta, viewed 14 September 2010 Jakarta, $<$ http://www.norway.or.id/Embassy/de velopment/Indonesia/governance/acehc ivilsociety/ 